\title{
MORPHOLOGICAL VARIABILITY OF MACROPHOMINA PHASEOLINA (TASSI) GOID. CHARCOAL ROT OF SORGHUM
}

\author{
KAVITHA. T. $\mathbf{R}^{1}$, SUNITHA. T. $\mathbf{R}^{2}$ \& BASAVARAJ NAIK. $\mathbf{T}^{3}$ \\ ${ }^{1}$ Assistant Professor, Department of Plant Pathology, College of Sericulture, Chintamani, Karnataka, India \\ ${ }^{2}$ Assistant Professor, Department of Agricultural Entomology, Karekere, Hassan, Karnataka, India \\ ${ }^{3}$ Senior Farm Superintendent, ZAHRS, UAHS, Shivamogga, Karnataka, India
}

\begin{abstract}
Twenty six isolates of Macrophomina phaseolina, causing charcoal rot of sorghum, obtained from different parts of Karnataka, Maharashtra and Andhra Pradesh, varied in their morphological characteristics. Colony diameter varied from 60.00 to $90.00 \mathrm{~mm}$. The higher mean colony diameter was observed in Raichur, Gadag, Gulberga-2, Amaravati, Mulegoan, Solapur, Ahmednagar, Kopargoan, Shirdi, Nanded and Nizamabad isolates. On the basis of colony color, isolates were divided into 4 groups, i.e. grayish white (Dharwad, Ushmanabad, Parbhani); blackish gray (Raichur, Gadag, Gulberga-1, Gulberga-2, Bidar, Ramnagar, Zalki, Solapur, Pune, Ahmednagar, Kopargoan, Nanded, Jalna, Nizamabad, Akola); deep black (Bijapur, Athani, Amaravati, Mulegoan, Tulajapur, Rahuri); cottony white color (Patancheru, Shirdi). Blackish gray, deep black and cottony white color. Ramnagar isolates produced bigger size of sclerotia (94.0 $\mu$ m). Rahuri isolate produced the highest number of sclerotia (60.3 sclerotia/microscopic field $10 \mathrm{X})$ and 110,135 and $180 \mathrm{sclerotia/9mm}$ disc during $2^{\text {nd }}$, $4^{\text {th }}$ and $6^{\text {th }}$ days after inoculation, respectively.
\end{abstract}

KEYWORDS: Macrophomina Phaseolina, Isolates, Morphological \& Variability

Received: Jul 07, 2017; Accepted: Jul 31, 2017; Published: Aug 07, 2017; Paper Id.: IJASRAUG201787

\section{INTRODUCTION}

Sorghum is the fifth most important cereal crop of the world. It forms the staple diet of the poor people of the world, located especially, in India and Africa. In other countries, it is used as fodder, cattle feed and as an industrial raw material. In India, sorghum is predominantly grown in Andhra Pradesh, Maharashtra, Karnataka and some parts of Tamil Nadu, Rajasthan and Madhya Pradesh. Charcoal rot of sorghum is one of the economically important diseases of sorghum, all over the world. It occurs in areas, where drought conditions generally prevail at or after flowering. The disease is favored by high soil temperature ranging from 30 to $42{ }^{\circ} \mathrm{c}$ and low soil moistures. Sorghum is grown both during Southwest monsoon (kharif) and post monsoon (rabi) season. Rabi crop produces high quality grains as they mature during winter season under clear dry and rain free climate. However, low levels of productivity in rabi sorghum is due to drought and is aggravated by charcoal rot disease, which usually appears at grain maturity stage and cause severe lodging. Most improved varieties and hybrids are susceptible to the disease. The loss in grain weight due to charcoal rot in rabi cultivars varies from18.53 to 63.22 per cent (Anon., 1999). A maximum 70.73 per cent grain weight loss has been reported in CSH13R, a high yielding commercial hybrid (Patil, 1980). The loss in grain yield is always more in rabi (40.83\%) than in kharif (17.69\%) (Patil, 1980). 


\section{MATERIAL AND METHODS}

Isolates of M. phaseolina were collected from different parts of Karnataka (Athani, Bidar, Bijapur, Dharwad, Gadag, Gulberga, Raichur); Maharashtra (Ahmednagar, Akola, Amaravati, Jalna, Kopargoan, Mulegoan, Nanded, Parbhani, Pune, Rahuri, Shirdi, Solapur, Tulajapur, Ushmanabad, Zalki) and Andhra Pradesh (Nizamabad, Patancheru, Ramnagar) constituting 26 infected sorghum samples in all. The morphological and cultural variability of the isolates was studied on the basis of various parameters such as colony color, texture, size, shape and number of sclerotia etc. For these studies, the isolates were grown and multiplied on potato dextrose agar (PDA) by inoculating half a centimeter disc of mycelial mat, taken from the periphery of seven days old culture of each of the 26 isolates. The plates were incubated at 27 $\left(1^{\circ} \mathrm{c}\right)$. Colony diameter on PDA media was recorded for the second day, till the growth completely covered the plates. Observations on sclerotial morphology were taken at 7 days old cultures.

\section{RESULTS AND DISCUSSIONS}

Data with regard to colony characteristics are presented in Table 1. Based on colony diameter, the higher mean colony diameter was observed in Raichur, Gadag, Gulberga-2, Amaravati, Mulegoan, Solapur, Ahmednagar, Kopargoan, Shirdi, Nanded and Nizamabad isolates, and a significantly lower mean colony diameter was observed in Bijapur and Tulajapur isolates. Based on colony color, the cultures were assigned to four groups, i.e. grayish white (Dharwad, Ushmanabad, Parbhani); blackish gray (Raichur, Gadag, Gulberga-1, Gulberga-2, Bidar, Ramnagar, Zalki, Solapur, Pune, Ahmednagar, Kopargoan, Nanded, Jalna, Nizamabad, Akola); deep black (Bijapur, Athani, Amaravati, Mulegoan, Tulajapur, Rahuri); cottony white color (Patancheru, Shirdi). The isolates also could be assigned to two groups on the basis of texture; fluffy colony produced by Dharwad, Amaravati, Shirdi, Parbhani isolates and flat colony produced by Raichur, Zalki,. Mulegoan, Solapur, Tulajapur, Ushmanabad, Pune, Ahmednagar, Kopargoan, Rahuri, Nanded, Jalna, Nizamabad and Akola isolates. These observations are in agreement with the findings of Shekhar et al., (2006), who reported that Coimbatore isolate produced maximum mycelial growth; the minimum was in Delhi isolate. Bangalore and Arabhavi isolates produced grayish white color; Udaipur and Hyderabad isolate produced blackish gray, Ludhiana and Delhi isolates produced deep black center with creams periphery and Coimbatore isolate produced cotton white color. Similarly, Coimbatore isolate produced thick fluffy growth and Delhi and Ludhiana isolates produced less fluffy growth.

The majority of the isolates took 2-3 days for sclerotial formation, except Bijapur isolates, which took four days for sclerotial formation (Table-2). Such variations, in days required for sclerotial formation have been reported by Subramaniam (1994), who noticed that most of the isolates took 3-4 days for sclerotial formation, except oil palm (OP1, OP2 and OP4), groundnut (Gn), soybean (So) and maize (Ma) isolates, which took 5-6 days for sclerotial formation. The size of the sclerotia varied from $94.0 \mu \mathrm{m}$ to $30.0 \mu \mathrm{m}$. It was observed that the Ramnagar isolate produced largest sclerotia of $94.0 \mu \mathrm{m}$; while the smallest size sclerotia of $30.0 \mu \mathrm{m}$ was produced by Bijapur isolate. Similar observations were reported by Shekhar et al., (2006), observed that the Hyderabad isolate produced largest sclerotia of $95.7 \mu \mathrm{m}$ followed by Bangalore, Udaipur, Ludhiana, Delhi, Arabhavi, while the smallest sized sclerotia of $66.9 \mu \mathrm{m}$ was noticed in Coimbatore isolate. Round shaped sclerotia were observed in Raichur, Bijapur, Gadag, Gulberga-1,Gulberga-2, Athani, Patancheru, Zalki, Mulegoan, Tulajapur, Pune, Ahmednagar, Kopargoan,Shirdi, Nanded, Jalns, Nizamabad and Akola isolates, while, the oblong shape of sclerotia were observed in Dharwad, Bidar, Ramnagar, Amaravati, Solapur, Ushmanabad, Rahuri and Parbhani isolates. Similarly Shekhar et al., (2006), observed that the Udaipur, Bangalore, Coimbatore isolates had an oblong shape, whereas, the other one had round shape sclerotia. The number of sclerotia of 60.3 per microscopic field $10 \mathrm{X}$ 
was recorded in Rahuri isolate, while, the minimum number of sclerotia 40.0 per microscopic field was observed in Ushmanabad isolate. Similar observations were made by Shekhar et al., (2006) that the maximum numbers of sclerotia /microscopic field (52.0) in Hyderabad isolate, while minimum number was observed in Coimbatore isolate (44/microscopic field).

\section{CONCLUSIONS}

The number of sclerotia $/ 9 \mathrm{~mm}$ disc varied from $110-50$ during $2^{\text {nd }}$ day, $135-72$ during $4^{\text {th }}$ and $180-100$ during $6^{\text {th }}$ days after inoculation (DAI) (Table-3). Among the isolates, Rahuri isolate had maximum number of sclerotia/9mm disc $(110,135$ and 180$)$ during $2^{\text {nd }}, 4^{\text {th }}$ and $6^{\text {th }}$ DAI, while, the minimum number was observed in Solapur (50) during $2^{\text {nd }}$ DAI, Ushmanabad (72) during $4^{\text {th }}$ DAI and Solapur, Ushmanabad, Ahmednagar (100) during $6^{\text {th }}$ DAI. Similar observations were made by Shekhar et al., (2006). They observed that Hyderabad isolate had maximum number of sclerotia/9 mm disc (180), while the minimum number was observed in Coimbatore isolate i.e., 169/9 mm disc.

\section{REFERENCES}

1. ANONYMOUS. (1999). Annual Report (1998-99) National Research Centre on sorghum, Hyderabad, pp. 110-115.

2. PATIL, S. H. (1980). Studies on charcoal rot of sorghum caused by Macrophomina phaseolina (Tassi) Goid. M. Sc. (Agri.) Thesis, University of Agricultural Sciences, Bangalore

3. SHEKHAR MEENA, SHARMA, R. C., LOKENDRA SINGH \& RAM DUTTA. (2006). Morphological and pathogenic variability of Macrophomina phaseolina (Tassi) Goid. Incitant of charcoal rot of maize in India. Indian Phytopathology, 59 (3), 294-298.

4. SUbRAmANiaM, J. (1994). Variation in Macrophomina phaseolina (Tassi) Goid. Causing charcoal rot of sorghum. Ph. D. Thesis, University of Agricultural Sciences, Dharwad

\section{APPENDICES}

Table 1: Growth Characters of 26 Isolates of M. Phaseolina from Sorghum on PDA

\begin{tabular}{|l|c|l|l|}
\hline \multicolumn{1}{|c|}{ Isolates } & Mean Colony Diameter(Mm) & Colony Colour & Colony Appearance \\
\hline $\mathrm{Ri}$ & 90.00 & Blackish gray & Flat colony \\
\hline $\mathrm{Bj}$ & 60.00 & Dark black & Flat colony \\
\hline $\mathrm{Ga}$ & 90.00 & Blackish gray & Flat colony \\
\hline $\mathrm{Gu}-1$ & 77.66 & Blackish gray & Flat colony \\
\hline $\mathrm{Gu}-2$ & 90.00 & Blackish gray & Flat colony \\
\hline $\mathrm{Dh}$ & 88.00 & Grayish white & Fluffy colony \\
\hline $\mathrm{Bo}$ & 79.33 & Blackish gray & Flat colony \\
\hline $\mathrm{At}$ & 88.00 & Dark black & Flat colony \\
\hline $\mathrm{Rm}$ & 89.66 & Blackish gray & Flat colony \\
\hline $\mathrm{Pa}$ & 85.00 & Cottony white & Flat colony \\
\hline $\mathrm{Am}$ & 90.00 & Dark black & Fluffy colony \\
\hline $\mathrm{Za}$ & 60.33 & Blackish gray & Flat colony \\
\hline $\mathrm{Mu}$ & 90.00 & Dark black & Flat colony \\
\hline $\mathrm{So}$ & 90.00 & Blackish gray & Flat colony \\
\hline $\mathrm{Tu}$ & 60.00 & Dark black & Flat colony \\
\hline $\mathrm{Us}$ & 88.00 & Grayish white & Flat colony \\
\hline $\mathrm{Pu}$ & 88.33 & Blackish gray & Flat colony \\
\hline $\mathrm{Ah}$ & 90.00 & Blackish gray & Flat colony \\
\hline $\mathrm{Ko}$ & 90.00 & Blackish gray & Flat colony \\
\hline $\mathrm{Ra}$ & 67.00 & Dark black & Flat colony \\
\hline
\end{tabular}




\begin{tabular}{|l|c|l|l|}
\hline \multicolumn{4}{|c|}{ Table 1: Contd., } \\
\hline $\mathrm{Sh}$ & 90.00 & Cottony white & Fluffy colony \\
\hline $\mathrm{Pr}$ & 80.33 & Grayish white & Fluffy colony \\
\hline $\mathrm{Na}$ & 90.00 & Blackish gray & Flat colony \\
\hline $\mathrm{Ja}$ & 75.00 & Blackish gray & Flat colony \\
\hline $\mathrm{Nz}$ & 90.00 & Blackish gray & Flat colony \\
\hline $\mathrm{Ak}$ & 88.33 & Blackish gray & Flat colony \\
\hline $\mathrm{SE} \mathrm{m} \pm$ & 0.942 & & \\
\hline $\mathrm{CD}$ at $1 \%$ & 3.55 & & \\
\hline
\end{tabular}

Table 2: Sclerotial Production by the Different Isolates of M. Phaseolina

\begin{tabular}{|c|c|c|c|c|}
\hline Isolates & $\begin{array}{l}\text { Days Taken for } \\
\text { Sclerotial Body } \\
\text { Formation }\end{array}$ & $\begin{array}{c}\text { Sclerotial } \\
\text { Diameter }(\square \mathbf{m})\end{array}$ & $\begin{array}{l}\text { Shape of } \\
\text { Sclerotia }\end{array}$ & $\begin{array}{c}\text { Number of } \\
\text { Sclerotia/Microscopic } \\
\text { Field }\end{array}$ \\
\hline $\mathrm{Ri}$ & 2 & 45.3 & Round & 42.3 \\
\hline $\mathrm{Bj}$ & 4 & 30.0 & Round & 48.6 \\
\hline $\mathrm{Ga}$ & 2 & 33.3 & Round & 45.0 \\
\hline $\mathrm{Gu}-1$ & 2 & 39.3 & Round & 50.0 \\
\hline $\mathrm{Gu}-2$ & 3 & 35.3 & Round & 49.3 \\
\hline $\mathrm{Dh}$ & 2 & 36.0 & Oblong & 42.3 \\
\hline Bo & 3 & 62.0 & Oblong & 47.3 \\
\hline At & 2 & 60.6 & Round & 44.0 \\
\hline $\mathrm{Rm}$ & 3 & 94.0 & Oblong & 49.6 \\
\hline $\mathrm{Pa}$ & 2 & 70.6 & Round & 48.3 \\
\hline $\mathrm{Am}$ & 2 & 89.3 & Oblong & 41.3 \\
\hline $\mathrm{Za}$ & 2 & 88.6 & Round & 44.6 \\
\hline $\mathrm{Mu}$ & 3 & 60.6 & Round & 42.6 \\
\hline So & 2 & 93.3 & Oblong & 39.6 \\
\hline $\mathrm{Tu}$ & 3 & 62.0 & Round & 45.0 \\
\hline Us & 3 & 88.6 & Oblong & 40.0 \\
\hline $\mathrm{Pu}$ & 2 & 84.6 & Round & 41.6 \\
\hline $\mathrm{Ah}$ & 3 & 84.0 & Round & 41.0 \\
\hline Ko & 3 & 81.3 & Round & 55.6 \\
\hline $\mathrm{Ra}$ & 2 & 34.0 & Oblong & 60.3 \\
\hline Sh & 2 & 36.0 & Round & 52.3 \\
\hline $\mathrm{Pr}$ & 3 & 51.3 & Oblong & 52.6 \\
\hline $\mathrm{Na}$ & 2 & 49.3 & Round & 51.6 \\
\hline $\mathrm{Ja}$ & 3 & 58.0 & Round & 51.0 \\
\hline $\mathrm{Nz}$ & 2 & 40.6 & Round & 46.6 \\
\hline $\mathrm{Ak}$ & 3 & 88.0 & Round & 54.3 \\
\hline SE m+ & & 0.716 & & 0.510 \\
\hline $\mathrm{CD}$ at $1 \%$ & & 2.70 & & 1.92 \\
\hline
\end{tabular}

Table 3: Number of Sclerotia per 9 mm Disc Produced by Isolates of M.Phaseolina at Different Intervals

\begin{tabular}{|l|c|c|c|}
\hline \multirow{2}{*}{ Isolates } & \multicolumn{3}{|c|}{ Number of Sclerotia per 9mm Disc } \\
\cline { 2 - 4 } & 2 DAI & 4 DAI & 6 DAI \\
\hline $\mathrm{Ri}$ & 60 & 79 & 105 \\
\hline $\mathrm{Bj}$ & 74 & 93 & 128 \\
\hline $\mathrm{Ga}$ & 71 & 89 & 118 \\
\hline $\mathrm{Gu}-1$ & 78 & 110 & 140 \\
\hline $\mathrm{Gu}-2$ & 70 & 95 & 130 \\
\hline $\mathrm{Dh}$ & 61 & 76 & 103 \\
\hline $\mathrm{Bo}$ & 70 & 92 & 123 \\
\hline $\mathrm{At}$ & 63 & 82 & 113 \\
\hline
\end{tabular}




\begin{tabular}{|l|c|c|c|}
\hline \multicolumn{4}{|c|}{ Table 3: Contd., } \\
\hline $\mathrm{Rm}$ & 75 & 99 & 135 \\
\hline $\mathrm{Pa}$ & 72 & 94 & 125 \\
\hline $\mathrm{Am}$ & 59 & 74 & 101 \\
\hline $\mathrm{Za}$ & 65 & 80 & 110 \\
\hline $\mathrm{Mu}$ & 61 & 80 & 110 \\
\hline $\mathrm{So}$ & 50 & 79 & 100 \\
\hline $\mathrm{Tu}$ & 69 & 85 & 115 \\
\hline $\mathrm{Us}$ & 57 & 72 & 100 \\
\hline $\mathrm{Pu}$ & 60 & 75 & 102 \\
\hline $\mathrm{Ah}$ & 57 & 73 & 100 \\
\hline $\mathrm{Ko}$ & 90 & 120 & 155 \\
\hline $\mathrm{Ra}$ & 110 & 135 & 180 \\
\hline $\mathrm{Sh}$ & 85 & 115 & 149 \\
\hline $\mathrm{Pr}$ & 86 & 118 & 150 \\
\hline $\mathrm{Na}$ & 83 & 115 & 145 \\
\hline $\mathrm{Ja}$ & 80 & 110 & 143 \\
\hline $\mathrm{Nz}$ & 70 & 90 & 120 \\
\hline $\mathrm{Ak}$ & 91 & 125 & 153 \\
\hline
\end{tabular}


